\title{
DISCLAIMER
}

This report was prepared as an account of work sponsored by an agency of the United States

BNL-52203

Government. Neither the United States Government nor any agency thereof, nor any of their

(Rev. 12/95)

UC-700 bility for the accuracy, completeness, or usefulness of any information, apparatus, product, or process disclosed, or represents that its use would not infringe privately owned rights. Reference herein to any specific commercial product, process, or service by trade name, trademark, manufacturer, or otherwise does not necessarily constitute or imply its endorsement, recommendation, or favoring by the United States Government or any agency thereof. The views and opinions of authors expressed herein do not necessarily state or reflect those of the United States Government or any agency thereof.

\section{U.S. STATUTES FOR ENFORCEMENT BY SECURITY INSPECTORS}

\author{
J.J. Cadwell \\ C.J. Ruger
}

December 1995

\author{
Engineering Technology Division \\ Department of Advanced Technology \\ Brookhaven National Laboratory \\ Upton, New York
}

Under the U.S. Department of Energy Contract DE-AC02-76CH00016 
DISCLAIMER

This report was prepared as an secount of work sponsored by an agency of the Unitod States Government. Neither the Unitod States Government nor any agency thereof, nor any of their employees, or eny of their contractors, subcontractors, or their employees, makes any warrantoc, expressed or impliod, or assumes any legal liabilities or responsibility for the accuracy, completeness, or usefulness of an information, apparatus, product, or process disclosod, or represeats thet its use would not infringe privately owned rights. Refereace berein to any spocific commercial product, process or service by trade name, trademark, manufacturer, or otherwise, does not necessarily constitute or imply its endorement, recommendetion, or favoring by the United States Government or any sgency, contractor, or wubcontractor thereof. The views and opinions of authors expressed herein do not necessarily tate or reflect those of the Unitod States Government or any agency, contractor or subcontractor thereof.

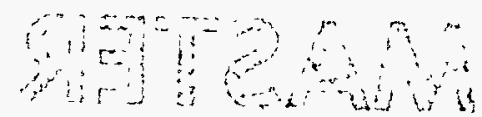


This document is one of a three volume set. BNL 52201 is titled, "Selected Text of Atomic Energy Act, Executive Orders and Other Laws of General Interest to Safeguards and Security Executives", and contains detailed information for use by executives. BNL 52202 is titled, "U.S. Statutes of General Interest to Safeguards and Security Officers", and contains less detail than BNL 52201. It is intended for use by officers. BNL 52203 is titled, "U.S. Statutes for Enforcement by Security Inspectors", and only contains statues to be applied by uniformed security inspections.

These are a newly updated version of a set of documents of similar titles published in September 1988, which were an updated version of an original set of documents published in November 1983. The first two versions were prepared by Jerry J. Cadwell, Esq. The current version was prepared by Jerry J. Cadwell, Esq. and Charles J. Ruger, both of the Engineering Technology Division, Brookhaven National Laboratory, Upton, New.York. They both wish to express their thanks to Jeanne Madaia, Ann Fort, and Janice DePass for their invaluable assistance in the final preparation of these documents. 


\section{CONTENTS}

I. Indexes

A. Index by Topic $\ldots \ldots \ldots \ldots \ldots \ldots \ldots \ldots \ldots \ldots \ldots \ldots \ldots \ldots \ldots$ ix

B. Index of Selected Portions of Title 18 of the Laws of the United States in Numerical Order.. ..................... xiii

II. Title 42. United States Code (Atomic Energy Act of 1954 as Amended)

- Selected Enforcement Provisions .......

Section

$\S 2201$ (k).General provisions $\ldots \ldots \ldots \ldots \ldots \ldots \ldots \ldots \ldots \ldots \ldots \ldots, 1$

$\S 2272$. Violation of specific sections $\ldots \ldots \ldots \ldots \ldots \ldots \ldots \ldots \ldots \ldots 1$

$\S 2273$. Violation of sections generally $\ldots \ldots \ldots \ldots \ldots \ldots \ldots \ldots \ldots, 2$

$\S 2274$. Communication of Restricted Data $\ldots \ldots \ldots \ldots \ldots \ldots \ldots$

§ 2275. Receipt of Restricted Data .................. 3

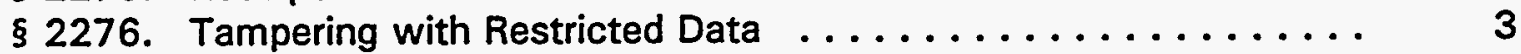

$\S 2278$. Trespass upon installations $\ldots \ldots \ldots \ldots \ldots \ldots \ldots \ldots \ldots, 4$

$\S 2278$ b. Photographing of installations $\ldots \ldots \ldots \ldots \ldots \ldots \ldots \ldots, 4$

III. Title 18. Crimes and Criminal Procedure - United States Coded ....... 5

A. SABOTAGe $\ldots \ldots \ldots \ldots \ldots \ldots \ldots \ldots \ldots \ldots \ldots \ldots \ldots \ldots \ldots \ldots \ldots \ldots \ldots$

Section

§ 2151. Definitions ........................ 5

\$ 2153. Destruction of war material, war premises, or war utilities .... 6

$\S 2154$. Production of defective war material, war premises, or war utilities . ........................ 6

$\S 2155$. Destruction of national-defense materials, national-defense premises or national-defense utilities $\ldots \ldots \ldots \ldots \ldots \ldots .7$

$\S 2156$. Production of defective national-defense material, nationalDefense premises or national-defense utilities $\ldots \ldots \ldots \ldots .7$

§ 33. Destruction of motor vehicles or motor vehicle facilities $\ldots . .7$ 


\section{CONTENTS}

Page

B. MISREPRESENTATION AND IMPERSONATION .............. 8

Section

§ 499. Military, naval, or official passes . . . . . . . . . . . $\quad 8$

$\S 701$. Official badges, identification cards, other insignia . . . . . 8

\$ 912. Officer or employee of the United States . . . . . . . . . . 8



C. THEFT AND EMBEZZLEMENT $\ldots \ldots \ldots \ldots \ldots \ldots \ldots \ldots \ldots \ldots \ldots$

Section

§ 641. Public money, property or records . . . . . . . . . . . 9

§ 831. Prohibited transactions involving nuclear materials ...... 9

\$ 2112. Personal property of United States . . . . . . . . . . . 13

D. MALICIOUS MISCHIEF $\ldots \ldots \ldots \ldots \ldots \ldots \ldots \ldots \ldots \ldots \ldots \ldots$

Section

$\S 1361 . \quad$ Government property or contracts . . . . . . . . . 13

$\S 1362$. Communication lines, stations or systems . . . . . . . . 14

$\S 1363$. Buildings or property within special maritime and territorial 14

jurisdiction ....................... 14

E. CONSPIRACY $\ldots \ldots \ldots \ldots \ldots \ldots \ldots \ldots \ldots \ldots \ldots \ldots \ldots \ldots \ldots \ldots$

Section

§ 371. Conspiracy to commit offense or to defraud United States . . 14

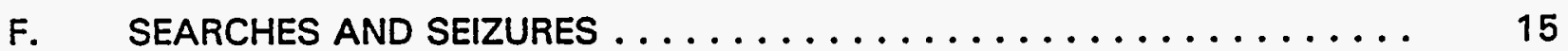

Section

$\S 2236 . \quad$ Searches without warrant $\ldots \ldots \ldots \ldots \ldots \ldots \ldots \ldots$ 
CONTENTS

Page

G. Miscellaneous $\ldots \ldots \ldots \ldots \ldots \ldots \ldots \ldots \ldots \ldots \ldots \ldots \ldots \ldots \ldots$

Section

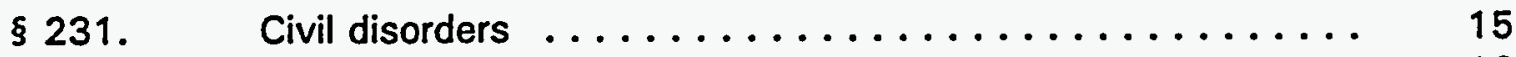

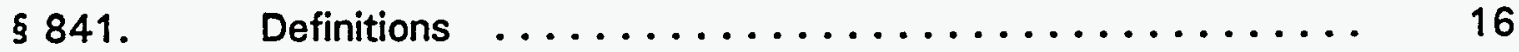

§ 844. Penalties (Use of Explosives or Fire) $\ldots \ldots \ldots \ldots \ldots \ldots . . \ldots 17$

$\S 2071$. Concealment, removal, or mutilation generally $\ldots \ldots \ldots .20$

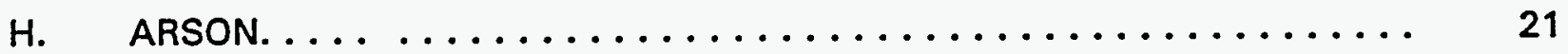

Section

§7. Special maritime and territorial jurisdiction of the United States defined $\ldots \ldots \ldots \ldots \ldots \ldots \ldots \ldots \ldots . \ldots \ldots$

§ 81. Arson within special maritime and territorial jurisdiction ... 22 


\section{INDEXES \\ A. INDEX BY TOPIC}

\begin{tabular}{|c|c|c|}
\hline & Citation' & Page \\
\hline Arrest Authority & $\begin{array}{l}\text { Sec. } 161(k) \\
42 \text { U.S.C. } \$ 2201(k)\end{array}$ & $\begin{array}{l}1 \\
1\end{array}$ \\
\hline Arson & 18 U.S.C. § 81,844 & 22,17 \\
\hline $\begin{array}{l}\text { Badges and Passes, Counterfeiting of } \\
\text { Civil Disorders }\end{array}$ & $\begin{array}{l}\text { Sec. } 223 \\
42 \text { U.S.C. § } 2273 \\
18 \text { U.S.C. § } 499,701 \\
18 \text { U.S.C. § } 231\end{array}$ & $\begin{array}{l}2 \\
2 \\
8 \\
15\end{array}$ \\
\hline $\begin{array}{l}\text { Classified Information } \\
\text { Concealment of U.S. Property }\end{array}$ & $\begin{array}{l}\text { Sec. } 224,225,226 \\
42 \text { U.S.C. } \$ 2274-2276 \\
18 \text { U.S.C. } \$ 2071\end{array}$ & $\begin{array}{l}3 \\
3 \\
20\end{array}$ \\
\hline $\begin{array}{l}\text { Conspiracy } \\
\text { General }\end{array}$ & 18 U.S.C. § 371 & 14 \\
\hline Conspiracy Generally & $\begin{array}{l}18 \text { U.S.C. \& } 371 \\
18 \text { U.S.C. \& } 2156\end{array}$ & $\begin{array}{l}14 \\
7\end{array}$ \\
\hline Counterfeiting of Badges and Passes & 18 U.S.C. $§ 499,701$ & 8 \\
\hline $\begin{array}{l}\text { Dangerous Weapons, Materials, etc. } \\
\text { Introduction of }\end{array}$ & $\begin{array}{l}\text { Sec. } 223 \\
42 \text { U.S.C. } \$ 2273\end{array}$ & $\begin{array}{l}2 \\
2\end{array}$ \\
\hline $\begin{array}{l}\text { Destruction of U.S. Property } \\
\text { Destruction of War Material } \\
\text { Malicious Mischief }\end{array}$ & $\begin{array}{l}18 \text { U.S.C. § } 2155 \\
18 \text { U.S.C. § } 1361 \text {, } \\
1362,1363\end{array}$ & $\begin{array}{l}7 \\
13 \\
14\end{array}$ \\
\hline $\begin{array}{l}\text { Production of War Material } \\
\text { Sabotage (covers Government and } \\
\text { War Material) }\end{array}$ & $\begin{array}{l}18 \text { U.S.C. § } 2154 \\
18 \text { U.S.C. § } 2151-2156\end{array}$ & $\begin{array}{c}6 \\
5-7\end{array}$ \\
\hline
\end{tabular}

\footnotetext{
' Sec. means a section of the Atomic Energy Act. Section means a section of this report.
} 


\section{A. INDEX BY TOPIC (Cont'd)}

Citation

Page

Destruction of Motor Vehicles

18 U.S.C. § 33

7

Disorders, Civil

18 U.S.C. § 231

15

Embezzlement

18 U.S.C. § 641

9

Explosives

18 U.S.C. § 844

17

Motor Vehicles, Destruction of

18 U.S.C. § 33

False Statements or Falsification Impersonation

Sec. 223

42 U.S.C. § 2273

2

2

Firearms Carrying by Inspector

Sec. $161(k)$

42 U.S.C. § 2201 (k)

1

18 U.S.C. § 844

Fire

Fissionable Material

See "Special Nuclear Material"

Forgery of Badges and Passes

Forgery

Passes

Sec. 223

42 U.S.C. § 2273

18 U.S.C. § 499,701

2

2

18 U.S.C. § 499

8

Sec. 223

42 U.S.C. § 2273

8

2

2

Fraud Against the Government

18 U.S.C. § 371

14

Impersonator

Officer of U.S.

Sec. 223

42. U.S.C. § 2273

2

18 U.S.C. § 641

9

18 U.S.C. § 1363

14

Malicious Mischief

18 U.S.C. § 33

7

Motor Vehicles, Destruction of

Mutilation of U.S. Property

18 U.S.C. § 2071

20 


\section{A. INDEX BY TOPIC (Cont'd)}

\begin{tabular}{|c|c|c|}
\hline & Citation & Page \\
\hline Off-site, Definition & $\begin{array}{l}\text { Sec. } 223 \\
42 \text { U.S.C. § } 2273 \\
18 \text { U.S.C. \$ } 499,701\end{array}$ & $\begin{array}{l}2 \\
2 \\
8\end{array}$ \\
\hline \multicolumn{3}{|l|}{ Passes (see Badges and Passes) } \\
\hline $\begin{array}{l}\text { Forgery } \\
\text { Unlawful Possession }\end{array}$ & $\begin{array}{l}18 \text { U.S.C. § } 499 \\
18 \text { U.S.C. § } 701\end{array}$ & $\begin{array}{l}8 \\
8\end{array}$ \\
\hline Passes and Badges, Counterfeiting of & 18 U.S.C. § 499, 701 & 8 \\
\hline $\begin{array}{l}\text { Photographing or Sketching } \\
\text { Commission Property }\end{array}$ & $\begin{array}{l}\text { Sec. } 230 \\
42 \text { U.S.C. § } 2278 \text { (b) }\end{array}$ & $\begin{array}{l}4 \\
4\end{array}$ \\
\hline $\begin{array}{l}\text { Records and Report - Concealment, } \\
\text { Removal or Mutilation }\end{array}$ & 18 U.S.C. § 2071 & 20 \\
\hline \multicolumn{3}{|l|}{ Restricted Data } \\
\hline Communication of & $\begin{array}{l}\text { Sec. } 224 \\
42 \text { U.S.C. } 2274\end{array}$ & $\begin{array}{l}3 \\
3\end{array}$ \\
\hline Receipt of & $\begin{array}{l}\text { Sec. } 225 \\
42 \text { US. } 2275\end{array}$ & $\begin{array}{l}3 \\
3\end{array}$ \\
\hline Tampering with & $\begin{array}{l}\text { Sec. } 226 \\
42 \text { U.S.C. } 2276\end{array}$ & $\begin{array}{l}3 \\
3\end{array}$ \\
\hline \multicolumn{3}{|l|}{$\begin{array}{l}\text { Restrictions on Certain Facilities, etc. } \\
\text { of Interest to DOE }\end{array}$} \\
\hline Entering & $\begin{array}{l}\text { Sec. } 222-230 \\
42 \text { U.S.C. \& } 2272-2278 b\end{array}$ & $\begin{array}{l}1-4 \\
1-4\end{array}$ \\
\hline $\begin{array}{l}\text { Introducing of Dangerous Weapons } \\
\text { or materials }\end{array}$ & $\begin{array}{l}\text { Sec. } 222-230 \\
42 \text { U.S.C. } 2272-2278 b\end{array}$ & $\begin{array}{l}1-4 \\
1-4\end{array}$ \\
\hline Photographing, Sketching, Flying Over & $\begin{array}{l}\text { Sec. } 230 \\
42 \text { U.S.C. § } 2278 b\end{array}$ & $\begin{array}{l}4 \\
4\end{array}$ \\
\hline Riots, Civil Disorders & 18 U.S.C:" § 231 & 15 \\
\hline Robbery & 18 U.S.C. $\S 2112$ & 13 \\
\hline $\begin{array}{l}\text { Search Warrant } \\
\text { Unlawful search }\end{array}$ & $\begin{array}{l}\text { Sec. } 222 \\
42 \text { U.S.C. § } 2272\end{array}$ & $\begin{array}{l}1 \\
1\end{array}$ \\
\hline
\end{tabular}




\section{A. INDEX BY TOPIC (Cont'd)}

Citation

Page

Special Maritime Jurisdiction

18 U.S.C. $\S 7$

Special Nuclear Material

Prohibited Transactions

18 U.S.C. § 831

9

Territorial Jurisdiction of U.S.

18 U.S.C. § 1363

14

Theft of Government Property

18 U.S.C. § 641,2112

9,13

Theft

18 U.S.C. § 641

9

Trespass on Commission Installation

Sec. 229

42 U.S.C. § $2278 a$

4

18 U.S.C. § 1361

13

Depredation Against Property

U.S. Property

Communication Lines (destruction)

Damage or Depredation

Destruction of War Material

Personal, Theft of

18 U.S.C. \$ 1362

14

18 U.S.C. \$ 1361

13

18 U.S.C. \$ 2153

6

18 U.S.C. § 2112

13

Violations

Injunction to Prevent

Penalties for Specific Sections Violation Generally

Sec. 222, 223

1,2

42 U.S.C. § $2272,2273 \quad 1,2$

42 U.S.C. § 2272

42 U.S.C. \& $2273 \quad 2$

War Material Def.

National Defense Material Def. National Defense Premises Def. National Defense Utilities Def.

War Premises Def.

War Utilities Def.

18 U.S.C. § 2151

5

18 U.S.C. \$ 2151

18 U.S.C. \& 2151

18 U.S.C. \& 2151

18 U.S.C. \& $2151 \quad 5$

18 U.S.C. § 2151 


\section{B. INDEX OF SELECTED PORTIONS OF TITLE 18 OF THE LAWS OF THE UNITED STATES IN NUMERICAL ORDER}

Page

I. TITLE 18: CRIMES AND CRIMINAL PROCEDURE

18 U.S.C. § 7. Special maritime and territorial jurisdiction of the United States defined ..............

18 U.S.C. \$33. Destruction of motor vehicles or motor vehicle facilities ..................

18 U.S.C. § 81. Arson within special maritime and territorial

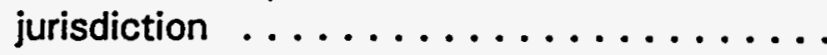

18 U.S.C. $\S 231$. Civil disorders $\ldots \ldots \ldots \ldots \ldots \ldots \ldots \ldots$

18 U.S.C. $\$ 371$. Conspiracy to commit offense or to defraud

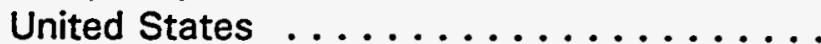

18 U.S.C. $\$ 499$. Military, naval, or official passes . . . . . . .

18 U.S.C. $\$ 701$. Official badges, identification cards other

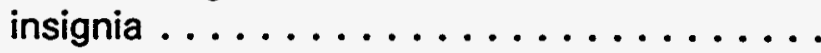

18 U.S.C. \$ 831. Prohibited transactions involving nuclear

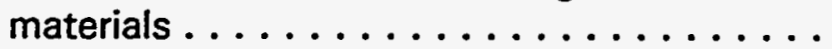

18 U.S.C. $\S 841$. Definitions (t Explosives) . . . . . . . . . 16

18 U.S.C. $\$ 844$. Penalties - († Use of explosives or fires) . . . 17

18 U.S.C. $\$ 912$. Officer or employee of the United States ... 8

18 U.S.C. \$ 913. Impersonator making arrest or search ..... 8

18 U.S.C. $\$ 1361$. Government property or contracts ....... 13

18 U.S.C. $\$ 1362$. Communication lines, stations, or systems . 
Page

18 U.S.C. $\$ 1363$. Buildings or property within special maritime and territorial jurisdiction ...........

18 U.S.C. $\$ 2071$. Concealment, removal, or mutilation generally

18 U.S.C. § 2112. Personal property of United States .... . .

18 U.S.C. $\S 2151$. Definitions . . . . . . . . . . . .

18 U.S.C. $\S 2153$. Destruction of war material, war premises, or war utilities ..................

18 U.S.C. § 2154. Production of defective war material, war premises, or war utilities ...............

18 U.S.C. $\$ 2155$. Destruction of national defense materials, national defense premises, or national defense utilities..

18 U.S.C. \$ 2156. Production of defective national defense material, national defense premises, or national defense utilities ...............

18 U.S.C. $\S 2236$. Searches without warrant $\ldots \ldots \ldots \ldots \ldots$ 


\section{TITLE 42. UNITED STATES CODE (ATOMIC ENERGY ACT OF 1954 AS AMENDED) SELECTED ENFORCEMENT PROVISIONS}

\section{U.S.C. $\$ 2201$ (Section 161). General provisions}

In the performance of its functions the Commission is authorized to--

(k) Carrying of firearms. authorize such of its members, officers, and employees as it deems necessary in the interest of the common defense and security to carry firearms while in the discharge of their official duties. The Commission may also authorize such of those employees of its contractors and subcontractors (at any tier) engaged in the . protection of property under the jurisdiction of the United States located at facilities owned by or contracted to the United States or being transported to or from such facilities as it deems necessary in the interests of the common defense and security to carry firearms while in the discharge of their official duties. A person authorized to carry firearms under this subsection may, while in the performance of, and in connection with, official duties, make arrests without warrant for any offense against the United States committed in that person's presence or for any felony cognizable under the laws of the United States if that person has reasonable grounds to believe that the individual to be arrested has committed or is committing such felony. An employee of a contractor or subcontractor authorized to carry firearms under this subsection may make such arrests only when the individual to be arrested is within, or in direct flight from, the area of such offense. A person granted authority to make arrests by this subsection may exercise that authority only in the enforcement of (1) laws regarding the property of the United States in the custody of the Department of Energy, the Nuclear Regulatory Commission, or a contractor of the Department of Energy or Nuclear Regulatory Commission, or (2) any provision of this Act that may subject an offender to a fine, imprisonment, or both. The arrest authority conferred by this subsection is in addition to any arrest authority under other laws. The Secretary, with the approval of the Attorney General, shall issue guidelines to implement this subsection;

\section{U.S.C. $\S 2272$ (Sec. 222). Violation of specific sections}

Whoever willfully violates, attempts to violate, or conspires to violate, any provision of sections 57,92 , or 101 [42 U.S.C. $\$ \S 2077,2122,2131$ ], or whoever unlawfully interferes, attempts to interfere, or conspires to interfere with any recapture or entry under section 108 [42 U.S.C. $\$ 2138$ ], shall, upon conviction thereof, be punished by a fine of not more than $\$ 10,000$ or by imprisonment for not more than ten years, or both, except that whoever commits such an offense with intent to injure the United States or with intent to secure an advantage to any foreign nation shall, upon conviction thereof, be punished by imprisonment for life, or by imprisonment for any term of years or a fine of not more than $\$ 20,000$ or both.

\footnotetext{
- Section numbers refer to the corrosponding section of the Atomic Energy Act of 1954.
} 
(a) Whoever willfully violates, attempts to violate, or conspires to violate, any provision of this Act for which no criminal penalty is specifically provided or of any regulation or order prescribed or issued under section 65 or subsections 161 (b), (i), or (o) [42 U.S.C. $\S \S 2095,2201$ (b), (i), (o)] shall, upon conviction thereof, be punished by a fine of not more than $\$ 5,000$ or by imprisonment for not more than two years, or both, except that whoever commits such an offense with intent to injure the United States or with intent to secure an advantage to any foreign nation, shall, upon conviction thereof, be punished by a fine of not more than $\$ 20,000$ or by imprisonment for not more than twenty years, or both.

(b) Any individual director, officer, or employee of a firm constructing, or supplying the components of any utilization facility required to be licensed under section 103 or 104 b. of this Act [42 U.S.C. $\S \S 2133$ or $2134(\mathrm{~b})$ ] who by act or omission, in connection with such construction or supply, knowingly and willfully violates or causes to be violated, any section of this Act, any rule, regulation, or order issued thereunder, or any license condition, which violation results, or if undetected could have resulted, in a significant impairment of a basic component of such a facility shall, upon conviction, be subject to a fine of not more than $\$ 25,000$ for each day of violation, or to imprisonment not to exceed two years, or both. If the conviction is for a violation committed after a first conviction under this subsection, punishment shall be a fine of not more than $\$ 50,000$ per day of violation, or imprisonment for not more than two years, or both. For the purposes of this subsection, the term 'basic component' means a facility structure, system, component or part thereof necessary to assure--

(1) the integrity of the reactor coolant pressure boundary,

the capability to shut-down the facility and maintain it in a safe shut-down condition, or

the capability to prevent or mitigate the consequences of accidents which could result in an unplanned offsite release of quantities of fission products in excess of the limits established by the Commission.

The provisions of this subsection shall be prominently posted at each site where a utilization facility required to be licensed under section 103 or $104 \mathrm{~b}$. of this Act [42 U.S.C. $\S \S 2133$ or $2134(\mathrm{~b})]$ is under construction and on the premises of each plant where components for such a facility are fabricated.

(c) Any individual director, officer or employee of a person indemnified under an agreement of indemnification under section 170 d. [42 U.S.C. $\$ 2210$ (d)] (or of a subcontractor or supplier theretol who, by act or omission, knowingly and willfully violates or causes to be violated any section of this Act or any applicable nuclear safety-related rule, regulation or order issued thereunder by the Secretary of Energy (or expressly incorporated by reference by the Secretary for purposes of nuclear safety, except any rule, regulation, or order issued by the Secretary of Transportation), which violation results in or, if undetected, would have resulted in a nuclear incident 
as defined in subsection 11 q. [42 U.S.C. \$ 2014(q)] shall, upon conviction, notwithstanding section 3571 of title 18, United States Code, be subject to a fine of not more than $\$ 25,000$, or to imprisonment not to exceed two years, or both. If the conviction is for a violation committed after the first conviction under this subsection, notwithstanding section 3571 of title 18, United States Code, punishment shall be a fine of not more than $\$ 50,000$, or imprisonment for not more than five years, or both.

\section{U.S.C. § 2274 (Sec. 224). Communication of Restricted Data}

Whoever, lawfully or unlawfully, having possession of, access to, control over, or being entrusted with any document, writing, sketch, photograph, plan, model, instrument, appliance, note, or information involving or incorporating Restricted Data--

(a) communicates, transmits, or discloses the same to any individual or person, or attempts or conspires to do any of the foregoing, with intent to injure the United States or with intent to secure an advantage to any foreign nation, upon conviction thereof, shall be punished by imprisonment for life, or by imprisonment for any term of years or a fine of not more than $\$ 20,000$ or both;

(b) communicates, transmits, or discloses the same to any individual or person, or attempts or conspires to do any of the foregoing, with reason to believe such data will be utilized to injure the United States or to secure an advantage to any foreign nation, shall, upon conviction, be punished by a fine of not more than $\$ 10,000$ or imprisonment for not more than ten years, or both.

\section{U.S.C. § 2275 (Sec. 225). Receipt of Restricted Data}

Whoever, with intent to injure the United States or with intent to secure an advantage to any foreign nation, acquires, or attempts or conspires to acquire any document, writing, sketch, photograph, plan, model, instrument, applicance, note, or information involving or incorporating Restricted Data shall, upon conviction thereof, be punished by imprisonment for life, or by imprisonment for any term of years or a fine of not more than $\$ 20,000$ or both.

\section{U.S.C. § 2276 (Sec. 226). Tampering with Restricted Data}

Whoever, with intent to injure the United States or with intent to secure an advantage to any foreign nation, removes, conceals, tampers with, alters, mutilates, or destroys any document, writing, sketch, photograph, plan, model, instrument, appliance, or note involving or incorporating Restricted Data and used by any individual or person in connection with the production of special nuclear material, or research or development relating to atomic energy, conducted by the United States, or financed in whole or in part by Federal funds, or conducted with the aid of special nuclear material, shall be punished by imprisonment for life, or by imprisonment for any term of years or a fine of not more than $\$ 20,000$ or both. 
(a) The Commission is authorized to issue regulations relating to the entry upon or carrying, transporting, or otherwise introducing or causing to be introduced any dangerous weapon, explosive, or other dangerous instrument or material likely to produce substantial injury or damage to persons or property, into or upon any facility, installation, or real property subject to the jurisdiction, administration, or in the custody of the Commission. Every such regulation of the Commission shall be posted conspicuously at the location involved.

(b) Whoever shall willfully violate any regulation of the Commission issued pursuant to subsection (a) shall, upon conviction thereof, be punishable by a fine of not more than $\$ 1,000$.

(c) Whoever shall willfully violate any regulation of the Commission issued pursuant to subsection (a) with respect to any installation or other property which is enclosed by a fence, wall, floor, roof, or other structural barrier shall be guilty of a misdemeanor and upon conviction thereof shall be punished by a fine of not to exceed $\$ 5,000$ or to imprisonment for not more than one year, or both.

\section{U.S.C. $\$ 2278 b$ (Sec. 230). Photographing of installations}

It shall be an offense, punishable by a fine of not more than $\$ 1,000$ or imprisonment for not more than one year, or both--

(1) to make any photograph, sketch, picture, drawing, map or graphical representation, while present on property subject to the jurisdiction, administration or in the custody of the Commission, of any installations or equipment designated by the President as requiring protection against the general dissemination of information relative thereto, in the interest of the common defense and security, without first obtaining the permission of the Commission, and promptly submitting the product obtained to the Commission for inspection or such other action as may be deemed necessary; or

(2) to use or permit the use of an aircraft or any contrivance used, or designed for navigation or flight in air, for the purpose of making a photograph, sketch, picture, drawing, map or graphical representation of any installation or equipment designated by the President as provided in the preceding paragraph, unless authorized by the Commission. 


\section{TITLE 18. CRIMES AND CRIMINAL PROCEDURE - UNITED STATES CODE}

\section{A. SABOTAGE}

\section{U.S.C. $\S 2151$. Definitions}

As used in this chapter [18 U.S.C. $\$ \S 2151$ et seq.]:

The words "war material" include arms, armament, ammunition, livestock, forage, forest products and standing timber, stores of clothing, air, water, food, foodstuffs, fuel, supplies, munitions, and all articles, parts or ingredients, intended for, adapted to, or suitable for the use of the United States or any associate nation, in connection with the conduct of war or defense activities.

The words "war premises" include all buildings, grounds, mines, or other places wherein such war material is being produced, manufactured, repaired, stored, mined, extracted, distributed, loaded, unloaded, or transported, together with all machinery and appliances therein contained; and all forts, arsenals, navy yards, camps, prisons, or other installations of the Armed Forces of the United States, or any associate nation.

The words "war utilities" include all railroads, railways, electric lines, roads of whatever description, any railroad or railway fixture, canal, lock, dam, wharf, pier, dock, bridge, building, structure, engine, machine, mechanical contrivance, car, vehicle, boat, aircraft, airfields, air lanes, and fixtures or appurtenances thereof, or any other means of transportation whatsoever, whereon or whereby such war material or any troops of the United States, or of any associate nation, are being or may be transported either within the limits of the United States or upon the high seas or elsewhere; and all air-conditioning systems, dams, reservoirs, aqueducts, water and gas mains and pipes, structures and buildings, whereby or in connection with which air, water or gas is being furnished, or may be furnished, to any war premises or to the Armed Forces of the United States, or any associate nation, and all electric light and power, steam or pneumatic power, telephone and telegraph plants, poles, wires, and fixtures, and wireless stations, and the buildings connected with the maintenance and operation thereof used to supply air, water, light, heat, power, or facilities of communication to any war premises or to the Armed Forces of the United States, or any associate nation.

The words "associate nation" mean any nation at war with any nation with which the United States is at war.

The words "national-defense material" include arms, armament, ammunition, livestock, forage, forest products and standing timber, stores of clothing, air, water, food, foodstuff, fuel, supplies, munitions, and all other articles of whatever description and any part or ingredient thereof, intended for, adapted to, or suitable for the use of the United States in connection with the national defense or for use in or in connection with the producing, manufacturing, repairing, storing, mining, extracting, distributing, loading, unloading, or transporting of any of the materials or other articles hereinbefore mentioned or any part or ingredient thereof. 
The words "national-defense premises" include all buildings, grounds, mines, or other places wherein such national-defense material is being produced, manufactured, repaired, stored, mined, extracted, distributed, loaded, unloaded, or transported, together with all machinery and appliances therein contained; and all forts, arsenals, navy yards, camps, prisons, or other installations of the Armed Forces of the United States.

The words "national-defense utilities" include all railroads, railways, electric lines, roads of whatever description, railroad or railway fixture, canal, lock, dam, wharf, pier, dock, bridge, building, structure, engine, machine, mechanical contrivance, car, vehicle, boat, aircraft, airfields, air lanes, and fixtures or appurtenances thereof, or any other means of transportation whatsoever, whereon or whereby such national-defense material, or any troops of the United States, are being or may be transported either within the limits of the United States or upon the high seas or elsewhere; and all air-conditioning systems, dams, reservoirs, aqueducts, water and gas mains and pipes, structures, and buildings, whereby or in connection with which air, water, or gas may be furnished to any national-defense premises or to the Armed Forces of the United States, and all electric light and power, steam or pneumatic power, telephone and telegraph plants, poles, wires, and fixtures and wireless stations, and the -buildings connected with the maintenance and operation thereof used to supply air, water, light, heat, power, or facilities of communication to any national-defense premises or to the Armed Forces of the United States.

\section{U.S.C. § 2153. Destruction of war material, war premises, or war utilities}

(a) Whoever, when the United States is at war, or in times of national emergency as declared by the President or by the Congress, with intent to injure, interfere with, or obstruct the United States or any associate nation in preparing for or carrying on the war or defense activities, or, with reason to believe that his act may injure, interfere with, or obstruct the United States or any associate nation in preparing for or carrying on the war or defense activities, willfully injures, destroys, contaminates or infects, or attempts to so injure, destroy, contaminate or infect any war material, war premises, or war utilities, shall be fined under this title or imprisoned not more than thirty years, or both.

(b) If two or more persons conspire to violate this section, and one or more of such persons do any act to effect the object of the conspiracy, each of the parties to such conspiracy shall be punished as provided in subsection (a) of this section.

\section{U.S.C. $\S 2154$. Production of defective war material, war premises, or war utilities}

(a) Whoever, when the United States is at war, or in times of national emergency as declared by the President or by the Congress, with intent to injure, interfere with, or obstruct the United States or any associate nation in preparing for or carrying on the war or defense activities, or, with reason to believe that his act may injure, interfere with, or obstruct the United States or any associate nation in preparing for or carrying on the war or defense activities, willfully makes, constructs, or causes to be made or constructed in a defective manner, or attempts to make, construct, or cause to be made or constructed in a defective manner any war material, war premises or war 
utilities, or any tool, implement, machine, utensil, or receptacle used or employed in making, producing, manufacturing, or repairing any such war material, war premises or war utilities, shall be fined under this title or imprisoned not more than thirty years, or both.

(b) If two or more persons conspire to violate this section, and one or more of such persons doany act to effect the object of the conspiracy, each of the parties to such conspiracy shall be punished as provided in subsection (a) of this section.

18 U.S.C. $\$ 2155$. Destruction of national-defense materials, national-defense premises or national-defense utilities

(a) Whoever, with intent to injure, interfere with, or obstruct the national defense of the United States, willfully injures, destroys, contaminates or infects, or attempts to so injure, destroy, contaminate or infect any national-defense material, national-defense premises, or national-defense utilities, shall be fined under this title or imprisoned not more than ten years, or both.

(b) If two or more persons conspire to violate this section, and one or more of such persons do any act to effect the object of the conspiracy, each of the parties to such conspiracy shall be punished as provided in subsection (a) of this section.

18 U.S.C. \$ 2156. Production of defective national-defense material, national-defense premises or national-defense utilities

(a) Whoever, with intent to injure, interfere with, or obstruct the national defense of the United States, willfully makes, constructs, or attempts to make or construct in a defective manner, any national-defense material, national-defense premises or nationaldefense utilities, or any tool, implement, machine, utensil, or receptacle used or employed in making, producing, manufacturing, or repairing any such national-defense material, national-defense premises or national-defense utilities, shall be fined under this title or imprisoned not more than ten years, or both.

(b) If two or more persons conspire to violate this section, and one or more of such persons do any act to effect the object of the conspiracy, each of the parties to such conspiracy shall be punished as provided in subsection (a) of this section.

\section{U.S.C. § 33. Destruction of motor vehicles or motor vehicle facilities}

Whoever willfully, with intent to endanger the safety of any person on board or anyone who he believes will board the same, or with a reckless disregard for the safety of human life, damages, disables, destroys, tampers with, or places or causes to be placed any explosive or other destructive substance in, upon, or in proximity to, any motor vehicle which is used, operated, or employed in interstate or foreign commerce, or its cargo or material used or intended to be used in connection with its operation; or 
Whoever willfully, with like intent, damages, disables, destroys, sets fire to, tampers with, or places or causes to be placed any explosive or other destructive substance in, upon, or in proximity to any garage, terminal, structure, supply, or facility used in the operation of, or in support of the operation of, motor vehicles engaged in interstate or foreign commerce or otherwise makes or causes such property to be made unworkable, unusable, or hazardous to work or use; or

Whoever, with like intent, willfully disables or incapacitates any driver or person employed in connection with the operation or maintenance of the motor vehicle, or in any way lessens the ability of such person to perform his duties as such; or

Whoever willfully attempts to do any of the aforesaid acts--

shall be fined under this title or imprisoned not more than twenty years, or both.

\section{B. MISREPRESENTATION AND IMPERSONATION}

\section{U.S.C. § 499. Military, naval, or official passes}

Whoever falsely makes, forges, counterfeits, alters, or tampers with any naval, military, or official pass or permit, issued by or under the authority of the United States, or with intent to defraud uses or possesses any such pass or permit, or personates or falsely represents himself to be or not to be a person to whom such pass or permit has been duly issued, or willfully allows any other person to have or use any such pass or permit, issued for his use alone, shall be fined under this title or imprisoned not more than five years, or both.

\section{U.S.C. $\$$ 701. Official badges, identification cards, other insignia}

Whoever manufactures, sells, or possesses any badge, identification card, or other insignia, of the design prescribed by the head of any department or agency of the United States for use by any officer or employee thereof, or any colorable imitation thereof, or photographs, prints, or in any other manner makes or executes any engraving, photograph, print, or impression in the likeness of any such badge, identification card, or other insignia, or any colorable imitation thereof, except as authorized under regulations made pursuant to law, shall be fined under this title or imprisoned not more than six months, or both.

\section{U.S.C. $\$ 912$. Officer or employee of the United States}

Whoever falsely assumes or pretends to be an officer or employee acting under the authority of the United States or any department, agency or officer thereof, and acts as such, or in such pretended character demands or obtains any money, paper, document, or thing of value, shall be fined under this title or imprisoned not more than three years, or both.

\section{U.S.C. § 913. Impersonator making arrest or search}

Whoever falsely represents himself to be an officer, agent, or employee of the United States, and in such assumed character arrests or detains any person or in any manner searches the 
person, buildings, or other property of any person, shall be fined under this title or imprisoned not more than three years, or both.

\section{THEFT AND EMBEZZLEMENT}

\section{U.S.C. \$ 641. Public money, property or records}

Whoever embezzles, steals, purloins, or knowingly converts to his use or the use of another, or without authority, sells, conveys or disposes of any record, voucher, money, or thing of value of the United States or of any department or agency thereof, or any property made or being made under contract for the United States or any department or agency thereof; or Whoever receives, conceals, or retains the same with intent to convert it to his use or gain, knowing it to have been embezzled, stolen, purloined or converted--

Shall be fined under this title or imprisoned not more than ten years, or both; but if the value of such property does not exceed the sum of $\$ 100$, he shall be fined under this title or imprisoned not more than one year, or both.

The word "value" means face, par, or market value, or cost price, either wholesale or retail, whichever is greater.

\section{U.S.C. § 831. Prohibited transactions involving nuclear materials}

(a) Whoever, if one of the circumstances described in subsection (c) of this section occurs--

(1) without lawful authority, intentionally receives, possesses, uses, transfers, alters, disposes of, or disperses any nuclear material and--

(A) thereby knowingly causes the death of or serious bodily injury to any person or substantial damage to property; or

(B) knows that circumstances exist which are likely to cause the death of or serious bodily injury to any person or substantial damage to property;

(2) with intent to deprive another of nuclear material, knowingly--

(A) takes and carries away nuclear material of another without authority;

(B) makes an unauthorized use, disposition, or transfer, of nuclear material belonging to another; or

(C) uses fraud and thereby obtains nuclear material belonging to another; 
(3) knowingly--

(A) uses force; or

(B) threatens or places another in fear that any person other than the actor will imminently be subject to bodily injury; and thereby takes nuclear material belonging to another from the person or presence of any other;

(4) intentionally intimidates any person and thereby obtains nuclear material belonging to another;

(5) with intent to compel any person, international organization, or governmental entity to do or refrain from doing any act, knowingly threatens to engage in conduct described in paragraph $(2)(A)$ or $(3)$ of this subsection;

(6) knowingly threatens to use nuclear material to cause death or serious bodily injury to any person or substantial damage to property under circumstances in which the threat may reasonably be understood as an expression of serious purposes;

(7) attempts to commit an offense under paragraph (1), (2), (3), or (4) of this subsection; or

(8) is a party to a conspiracy of two or more persons to commit an offense under paragraph (1), (2), (3), or (4) of this subsection, if any of the parties intentionally engages in any conduct in furtherance of such offense; shall be punished as provided in subsection (b) of this section.

(b) The punishment for an offense under--

(1) paragraphs (1) through (7) of subsection (a) of this section is--

(A) a fine under this title; and

(B) imprisonment--

(i) for any term of years or for life (I) if, while committing the offense, the offender knowingly causes the death of any person; or (II) if, while committing an offense under paragraph (1) or (3) of subsection (a) of this section, the offender, under circumstances manifesting extreme indifference to the life of an individual, knowingly engages in any conduct and thereby recklessly causes the death of or serious bodily injury to any person; and

(ii) for not more than 20 years in any other case; and 
(A) a fine under this title; and

(B) imprisonment--

(i) for not more than 20 years if the offense which is the object of the conspiracy is punishable under paragraph (1)(B)(i); and

(ii) for not more than 10 years in any other case.

(c) The circumstances referred to in subsection (a) of this section are that--

(1) the offense is committed in the United States or the. special maritime and territorial jurisdiction of the United States, or the special aircraft jurisdiction of the United States (as defined in section 46501 of title 49);

(2) the defendant is a national of the United States, as defined in section 101 of the Immigration and Nationality Act (8 U.S.C. 1101);

(3) at the time of the offense the nuclear material is in use, storage, or transport, for peaceful purposes, and after the conduct required for the offense occurs the defendant is found in the United States, even if the conduct required for the offense occurs outside the United States; or

(4) the conduct required for the offense occurs with respect to the carriage of a consignment of nuclear material for peaceful purposes by any means of transportation intended to go beyond the territory of the state where the shipment originates beginning with the departure from a facility of the shipper in that state and ending with the arrival at a facility of the receiver within the state of ultimate destination and either of such states is the United States.

(d) The Attorney General may request assistance from the Secretary of Defense under chapter 18 of title 10 [10 U.S.C. $\$ \S 371$ et seq.] in the enforcement of this section and the Secretary of Defense may provide such assistance in accordance with chapter 18 of title 10 [10 U.S.C. $\$ \S 371$ et seq.], except that the Secretary of Defense may provide such assistance through any Department of Defense personnel.

(e) (1) The Attorney General may also request assistance from the Secretary of Defense under this subsection in the enforcement of this section. Notwithstanding section 1385 of this title, the Secretary of Defense may, in accordance with other applicable law, provide such assistance to the Attorney General if--

(A) an emergency situation exists (as jointly determined by the Attorney General and the Secretary of Defense in their discretion); and 
(B) the provision of such assistance will not adversely affect the military preparedness of the United States (as determined by the Secretary of Defense in such Secretary's discretion).

(2) As used in this subsection, the term "emergency situation" means a circumstance--

(A) that poses a serious threat to the interests of the United States; and

(B) in which--

(i) enforcement of the law would be seriously impaired if the assistance were not provided; and

(ii) civilian law enforcement personnel are not capable of enforcing the law.

(3) Assistance under this section may include--

(A) use of personnel of the Department of Defense to arrest persons and conduct searches and seizures with respect to violations of this section; and

(B) such other activity as is incidental to the enforcement of this section, or to the protection of persons or property from conduct that violates this section.

(4) The Secretary of Defense may require reimbursement as a condition of assistance under this section.

(5) The Attorney General may delegate the Attorney General's function under this subsection only to a Deputy, Associate, or Assistant Attorney General.

(f) As used in this section--

(1) the term "nuclear material" means material containing any--

(A) plutonium with an isotopic concentration not in excess of 80 percent plutonium 238;

(B) uranium not in the form of ore or ore residue that contains the mixture of isotopes as occurring in nature;

(C) uranium that contains the isotope 233 or 235 or both in such amount that the abundance ratio of the sum of those isotopes to the isotope 238 is greater than the ratio of the isotope 235 to the isotope 238 occurring in nature; or 
(D) uranium 233;

(2) the term "international organization" means a public international organization designated as such pursuant to section 1 of the International Organizations Immunities Act (22 U.S.C. 288) or a public organization created pursuant to treaty or other agreement under international law as an instrument through or by which two or more foreign governments engage in some aspect of their conduct of international affairs;

(3) the term "serious bodily injury" means bodily injury which involves--

- (A) a substantial risk of death;

(B) extreme physical pain;

(C) protracted and obvious disfigurement; or

(D) protracted loss or impairment of the function of a bodily member, organ, or mental faculty; and

(4) the term "bodily injury" means--

(A) a cut, abrasion, bruise, burn, or disfigurement;

(B) physical pain;

(C) illness;

(D) impairment of a function of a bodily member, organ, or mental faculty; or

(E) any other injury to the body, no matter how temporary.

\section{U.S.C. § 2112. Personal property of United States}

Whoever robs or attempts to rob another of any kind or description of personal property belonging to the United States, shall be imprisoned not more than fifteen years.

\section{MALICIOUS MISCHIEF}

\section{U.S.C. $\$ 1361$. Govermment property or contracts}

Whoever willfully injures or commits any depredation against any property of the United States, or of any department or agency thereof, or any property which has been or is being manufactured or constructed for the United States, or any department or agency thereof, or attempts to commit any of the foregoing offenses shall be punished as follows: 
If the damage or attempted damage to such property exceeds the sum of $\$ 100$, by a fine [of] under this title or imprisonment for not more than ten years, or both; if the damage or attempted damage to such property does not exceed the sum of $\$ 100$, by a fine [of] under this title or by imprisonment for not more than one year, or both.

\section{U.S.C. § 1362. Communication lines, stations or systems}

Whoever willfully or maliciously injures or destroys or attempts willfully or maliciously to injure or destroy any of the works, property, or material of any radio, telegraph, telephone or cable, line, station, or system, or other means of communication, operated or controlled by the United States, or used or intended to be used for military or civil defense functions of the United States, whether constructed or in process of construction, or willfully or maliciously interferes in any way with the working or use of any such line, or system, or willfully or maliciously obstructs, hinders, or delays the transmission of any communication over any such line, or system, shall be fined under this title or imprisoned not more than ten years, or both.

In the case of any works, property, or material, not operated or controlled by the United States, this section shall not apply to any lawful strike activity, or other lawful concerted activities for the purposes of collective bargaining or other mutual aid and protection which do not injure or destroy any line or system used or intended to be used for the military or civil defense functions of the United States.

\section{U.S.C. $\S 1363$. Buildings or property within special maritime and territorial jurisdiction}

Whoever, within the special maritime and territorial jurisdiction of the United States, willfully and maliciously destroys or injures or attempts to destroy or injure any building, structure or vessel, any machinery or building materials and supplies, military or naval stores, munitions of war or any structural aids or applicances for navigation or shipping, shall be fined under this title or imprisoned not more than five years, or both, and if the building be a dwelling, or the life of any person be placed in jeopardy, shall be fined under this title or imprisoned not more than twenty years, or both.

\section{E. CONSPIRACY}

\section{U.S.C. \$ 371. Conspiracy to commit offense or to defraud United States}

If two or more persons conspire either to commit any offense against the United States, or to defraud the United States, or any agency thereof in any manner or for any purpose, and one or more of such persons do any act to effect the object of the conspiracy, each shall be fined under this title or imprisoned not more than five years, or both.

If, however, the offense, the commission of which is the object of the conspiracy, is a misdemeanor only, the punishment for such conspiracy shall not exceed the maximum punishment provided for such misdemeanor. 


\section{F. SEARCHES AND SEIZURES}

\section{U.S.C. \$ 2236. Searches without warrant}

Whoever, being an officer, agent, or employee of the United States or any department or agency thereof, engaged in the enforcement of any law of the United States, searches any private dwelling used and occupied as such dwelling without a warrant directing such search, or maliciously and without reasonable cause searches any other building or property without a search warrant, shall be fined for a first offense not more than \$1,000; and, for a subsequent offense, shall be fined not more than $\$ 1,000$ or imprisoned not more than one year, or both.

This section shall not apply to any person--

(a) serving a warrant of arrest; or

(b) arresting or attempting to arrest a person committing or attempting to commit an offense in his presence, or who has committed or is suspected on reasonable grounds of having committed a felony; or

(c) making a search at the request or invitation or with the consent of the occupant of the premises.

\section{G. MiscellaneOUS}

\section{U.S.C. § 231. Civil disorders}

(a) (1) Whoever teaches or demonstrates to any other person the use, application, or making of any firearm or explosive or incendiary device, or technique capable of causing injury or death to persons, knowing or having reason to know or intending that the same will be unlawfully employed for use in, or in furtherance of, a civil disorder which may in any way or degree obstruct, delay, or adversely affect commerce or the movement of any article or commodity in commerce or the conduct or performance of any federally protected function; or

(2) Whoever transports or manufactures for transportation in commerce any firearm, or explosive or incendiary device, knowing or having reason to know or intending that the same will be used unlawfully in furtherance of a civil disorder; or

(3) Whoever commits or attempts to commit any act to obstruct, impede, or interfere with any fireman or law enforcement officer lawfully engaged in the lawful performance of his official duties incident to and during the commission of a civil disorder which in any way or degree obstructs, delays, or adversely affects commerce or the movement of any article or commodity in commerce or the conduct or performance of any federally protected function--

Shall be fined under this title or imprisoned not more than five years, or both. 
(b) Nothing contained in this section shall make unlawful any act of any law enforcement officer which is performed in the lawful performance of his official duties.

\section{U.S.C. $\$ 841$. Definitions}

As used in this chapter [18 U.S.C. §§ 841 et seq.]--

(a) "Person" means any individual, corporation, company, association, firm, partnership, society, or joint stock company.

(b) "Interstate or foreign commerce" means commerce between any place in a State and any place outside of that State, or within any possession of the United States (not including the Canal Zone) or the District of Columbia, and commerce between places within the same State but through any place outside of that State. "State" includes the District of Columbia, the Commonwealth of Puerto Rico, and the possessions of the United States (not including the Canal Zone).

(c) "Explosive materials" means explosives, blasting agents, and detonators.

(d) Except for the purposes of subsections (d), (e), (f), (g), (h), (i), and (j) of section 844 of this title [18 U.S.C. $\$ 844(\mathrm{~d})$-(j)], "explosive" means any chemical compound mixture, or device, the primary or common purpose of which is to function by explosion; the term includes, but is not limited to, dynamite and other high explosives, black powder, pellet powder, initiating explosives, detonators, safety fuses, squibs, detonating cord, igniter cord, and igniters. The Secretary shall publish and revise at least annually in the Federal Register a list of these and any additional explosives which he determines to be within the coverage of this chapter. For the purposes of subsections (d), (e), (f), (g), (h), and (i) of section 844 of this title [18 U.S.C. § 844(d)(j)], the term "explosive" is defined in subsection (j) of such section 844 [18 U.S.C. § 844(j)].

(e) "Blasting agent" means any material or mixture, consisting of fuel and oxidizer, intended for blasting, not otherwise defined as an explosive: Provided, That the finished product, as mixed for use or shipment, cannot be detonated by means of a numbered 8 test blasting cap when unconfined.

(f) "Detonator" means any device containing a detonating charge that is used for initiating detonation in an explosive; the term includes, but is not limited to, electric blasting caps of instantaneous and delay types, blasting caps for use with safety fuses and detonating-cord delay connectors.

(g) "Importer" means any person engaged in the business of importing or bringing explosive materials into the United States for purposes of sale or distribution.

(h) "Manufacturer" means any person engaged in the business of manufacturing explosive materials for purposes of sale or distribution or for his own use. 
(i) "Dealer" means any person engaged in the business of distributing explosive materials at wholesale or retail.

(j) "Permittee" means any user of explosives for a lawful purpose, who has obtained a user permit under the provisions of this chapter [18 U.S.C. $\S \S 841$ et seq.].

(k) "Secretary" means the Secretary of the Treasury or his delegate.

(I) "Crime punishable by imprisonment for a term exceeding one year" shall not mean (1) any Federal or State offenses pertaining to antitrust violations, unfair trade practices, restraints of trade, or other similar offenses relating to the regulation of business practices as the Secretary may be regulation designate, or (2) any State offense (other than one involving a firearm or explosive) classified by the laws of the State as a misdemeanor and punishable by a term of imprisonment of two years or less.

(m) "Licensee" means any importer, manufacturer, or dealer licensed under the provisions of this chapter [18 U.S.C. $\$ \S 841$ et seq.].

(n) "Distribute" means sell, issue, give, transfer, or otherwise dispose of.

\section{U.S.C. $\$$ 844. Penalties (Use of Explosives or Fire)*}

(a) Any person who violates subsections (a) through (i) of section 842 of this chapter [18 U.S.C. $\S 842(a)-(i)]$ shall be fined under this title or imprisoned not more than ten years, or both.

(b) Any person who violates any other provision of section 842 of this chapter [18 U.S.C. § 842] shall be fined under this title or imprisoned not more than one year, or both.

(c) (1) Any explosive materials involved or used or intended to be used in any violation of the provisions of this chapter or any other rule or regulation promulgated thereunder or any violation of any criminal law of the United States shall be subject to seizure and forfeiture, and all provisions of the Internal Revenue Code of 1954 [26 U.S.C. $\S \S 1$ et seq.] relating to the seizure, forfeiture, and disposition of firearms, as defined in section 5845 (a) of that Code [26 U.S.C. \$ $5845(a)$ ], shall, so far as applicable, extend to seizures and forfeitures under the provisions of this chapter [18 U.S.C. $\S \S 841$ et seq.].

\footnotetext{
Author's Note: IDCFR $1047.4(\mathrm{a})(1)(\mathrm{i})(\mathrm{H})$ limits the authority of a DOE protective force officer to section (f) and $(\mathrm{g})$ of 18 U.S.C. $\$ 844$.
} 
(2) Notwithstanding paragraph (1), in the case of the seizure of any explosive materials for any offense for which the materials would be subject to forfeiture in which it would be impracticable or unsafe to remove the materials to a place of storage or would be unsafe to store them, the seizing officer may destroy the explosive materials forthwith. Any destruction under this paragraph shall be in the presence of at least 1 credible witness. The seizing officer shall make a report of the seizure and take samples as the Secretary may by regulation prescribe.

(3) Within 60 days after any destruction made pursuant to paragraph (2), the owner of (including any person having an interest in) the property so destroyed may make application to the Secretary for reimbursement of the value of the property. If the claimant establishes to the satisfaction of the Secretary that--

(A) the property has not been used or involved in a violation of law; or

(B) any unlawful involvement or use of the property was without the claimant's knowledge, consent, or willful blindness, the Secretary shall make an allowance to the claimant not exceeding the value of the property destroyed.

(d) Whoever transports or receives, or attempts to transport or receive, in interstate or foreign commerce any explosive with the knowledge or intent that it will be used to kill, injure, or intimidate any individual or unlawfully to damage or destroy any building, vehicle, or other real or personal property, shall be imprisoned for not more than ten years, or fined under this title, or both; and if personal injury results to any person, including any public safety officer performing duties as a direct or proximate result of conduct prohibited by this subsection, shall be imprisoned for not more than twenty years or fined under this title, or both; and if death results to any person, including any public safety officer performing duties as a direct or proximate result of conduct prohibited by this subsection, shall be subject to imprisonment for any term of years, or to the death penalty or to life imprisonment.

(e) Whoever, through the use of the mail, telephone, telegraph, or other instrument of commerce, willfully makes any threat, or maliciously conveys false information knowing the same to be false, concerning an attempt or alleged attempt being made, or to be made, to kill, injure, or intimidate any individual or unlawfully to damage or destroy any building, vehicle, or other real or personal property by means of fire or an explosive shall be imprisoned for not more than five years or fined under this title, or both.

(f) Whoever maliciously damages, or destroys, or attempts to damage or destroy, by means of fire or an explosive, any building, vehicle, or other personal or real property in whole or in part owned, possessed, or used by, or leased to, the United States, any department or agency thereof, or any institution or organization receiving Federal financial assistance shall be imprisoned for not more than 20 years, fined the greater of the fine under this title or the cost of repairing or replacing any property that is damaged or destroyed,[,] or both; and if personal injury results to any person, including 
any public safety officer performing duties as a direct or proximate result of conduct prohibited by this subsection, shall be imprisoned for not more than 40 years, fined the greater of the fine under this title or the cost of repairing or replacing any property that is damaged or destroyed, [, $]$ or both; and if death results to any person, including any public safety officer performing duties as a direct or proximate result of conduct prohibited by this subsection, shall be subject to imprisonment for any term of years, or to the death penalty or to life imprisonment.

(g) (1) Except as provided in paragraph (2), whoever possesses an explosive in an airport that is subject to the regulatory authority of the Federal Aviation Administration, or in any building in whole or in part owned, possessed, or used by, or leased to, the United States or any department or agency thereof, except with the written consent of the agency, department, or other person responsible for the management of such building or airport, shall be imprisoned for not more than five years, or fined under this title, or both.

(2) The provisions of this subsection shall not be applicable to--

(A) the possession of ammunition (as that term is defined in regulations issued pursuant to this chapter [18 U.S.C. $\S \S 841$ et seq.]) in an airport that is subject to the regulatory authority of the Federal Aviation Administration if such ammunition is either in checked baggage or in a closed container; or

(B) the possession of an explosive in an airport if the packaging and transportation of such explosive is exempt from, or subject to and in accordance with, regulations of the Research and Special Projects Administration for the handling of hazardous materials pursuant to chapter 51 of title 49 [49 U.S.C. § 5101 et seq.].

(h) Whoever--

(1) uses fire or an explosive to commit any felony which may be prosecuted in a court of the United States, or

(2) carries an explosive during the commission of any felony which may be prosecuted in a court of the United States, including a felony which provides for an enhanced punishment if committed by the use of a deadly or dangerous weapon or device shall, in addition to the punishment provided for such felony, be sentenced to imprisonment for 5 years but not more than 15 years. In the case of a second or subsequent conviction under this subsection, such person shall be sentenced to imprisonment for 10 years but not more than 25 years. Notwithstanding any other provision of law, the court shall not place on probation or suspend the sentence of any person convicted of a violation of this subsection, nor shall the term of imprisonment imposed under this subsection run concurrently with any other term of imprisonment including that imposed for the felony in which the explosive was used or carried. 
Whoever maliciously damages or destroys, or attempts to damage or destroy, by means of fire or an explosive, any building, vehicle, or other real or personal property used in interstate or foreign commerce or in any activity affecting interstate or foreign commerce shall be imprisoned for not more than 20 years, fined the greater of the fine under this title or the cost of repairing or replacing any property that is damaged or destroyed, [,] or both; and if personal injury results to any person, including any public safety officer performing duties as a direct or proximate result of conduct prohibited by this subsection, shall be imprisoned for not more than 40 years, fined the greater of the fine under this title or the cost of repairing or replacing any property that is damaged or destroyed[,], or both; and if death results to any person, including any public safety officer performing duties as a direct or proximate result of conduct prohibited by this subsection, shall also be subject to imprisonment for any term of years, or to the death penalty or to life imprisonment. No person shall be prosecuted, tried, or punished for any noncapital offense under this subsection unless the indictment is found or the information is instituted within 7 years after the date on which the offense was committed.

(j) For the purposes of subsections (d), (e), (f), (g), (h), and (i) of this section, the term "explosive" means gunpowders, powders used for blasting, all forms of high explosives, blasting materials, fuzes (other than electric circuit breakers), detonators, and other detonating agents, smokeless powders, other explosive or incendiary devices within the meaning of paragraph (5) of section 232 of this title, and any chemical compounds, mechanical mixture, or device that contains any oxidizing and combustible units, or other ingredients, in such proportions, quantities, or packing that ignition by fire, by friction, by concussion, by percussion, or by detonation of the compound, mixture, or device or any part thereof may cause an explosion.

(k) A person who steals any explosives materials which are moving as, or are a part of, or which have moved in, interstate or foreign commerce shall be imprisoned for not more than 10 years, fined under this title, or both.

(I) A person who steals any explosive material from a licensed importer, licensed manufacturer, or licensed dealer, or from any permittee shall be fined under this title, imprisoned not more than 10 years, or both.

(m) A person who conspires to commit an offense under subsection (h) shall be imprisoned for any term of years not exceeding 20 , fined under this title, or both.

\section{U.S.C. $\$ 2071$. Concealment, removal, or mutilation generally}

(a) Whoever willfully and unlawfully conceals, removes, mutilates, obliterates, or destroys, or attempts to do so, or, with intent to do so takes and carries away any record, proceeding, map, book, paper, document, or other thing, filed or deposited with any clerk or officer of any court of the United States, or in any public office, or with any judicial or public officer of the United States, shall be fined under this title or imprisoned not more than three years, or both. 
(b) Whoever, having the custody of any such record, proceeding, map, book, document, paper, or other thing, willfully and unlawfully conceals, removes, mutilates, obliterates, falsifies, or destroys the same, shall be fined under this title or imprisoned not more than three years, or both; and shall forfeit his office and be disqualified from holding any office under the United States. As used in this subsection, the term "office" does not include the office held by any person as a retired officer of the Armed Forces of the United States.

\section{H. ARSON}

\section{U.S.C. \$ 7. Special maritime and territorial jurisdiction of the United States defined}

The term "special maritime and territorial jurisdiction of the United States", as used in this title, includes:

(1) The high seas, any other waters within the admiralty and maritime jurisdiction of the United States and out of the jurisdiction of any particular State, and any vessel belonging in whole or in part to the United States or any citizen thereof, or to any corporation created by or under the laws of the United States, or of any State, Territory, District, or possession thereof, when such vessel is within the admiralty and maritime jurisdiction of the United States and out of the jurisdiction of any particular State.

(2) Any vessel registered, licensed, or enrolled under the laws of the United States, and being on a voyage upon the waters of any of the Great Lakes, or any of the waters connecting them, or upon the Saint Lawrence River where the same constitutes the International Boundary Line.

(3) Any lands reserved or acquired for the use of the United States, and under the exclusive or concurrent jurisdiction thereof, or any place purchased or otherwise acquired by the United States by consent of the legislature of the State in which the same shall be, for the erection of a fort, magazine, arsenal, dockyard, or other needful building.

(4) Any island, rock, or key containing deposits of guano, which may, at the discretion of the President, be considered as appertaining to the United States.

(5) Any aircraft belonging in whole or in part to the United States, or any citizen thereof, or to any corporation created by or under the laws of the United States, or any State, Territory, district, or possession thereof, while such aircraft is in flight over the high seas, or over any other waters within the admiralty and maritime jurisdiction of the United States and out of the jurisdiction of any particular State. 
(6) Any vehicle used or designed for flight or navigation in space and on the registry of the United States pursuant to the Treaty on Principles Governing the Activities of States in the Exploration and Use of Outer Space, Including the Moon and Other Celestial Bodies and the Convention on Registration of Objects Launched into Outer Space, while that vehicle is in flight, which is from the moment when all external doors are closed on Earth following embarkation until the moment when one such door is opened on Earth for disembarkation or in the case of a forced landing, until the competent authorities take over the responsibility for the vehicle and for persons and property aboard.

(7) Any place outside the jurisdiction of any nation with respect to an offense by or against a national of the United States.

(8) To the extent permitted by international law, any foreign vessel during a voyage having a scheduled departure from or arrival in the United States with respect to an offense committed by or against a national of the United States.

\section{U.S.C. \$ 81. Arson within special maritime and territorial jurisdiction}

Whoever, within the special maritime and territorial jurisdiction of the United States, willfully and maliciously sets fire to or burns, or attempts to set fire to or burn any building, structure or vessel, any machinery or building materials or supplies, military or naval stores, munitions of war, or any structural aids or appliances for navigation or shipping, shall be fined under this title or imprisoned not more than five years, or both.

If the building be a dwelling or if the life of any person be placed in jeopardy, he shall be fined under this title or imprisoned not more than twenty years, or both. 